\title{
4. Building resilience in the war zone against hidden injury
}

\section{COMMIJNTARY}

Psychological impacts of covering trauma such as war, or indeed any disaster with loss of life and tragedy, have the capacity to challenge the media professional to develop professional and personal skills. 'Lessons learned' from experience will enhance capacity considerably; however there are also the potential negative effects that can cause harm to some. These effects are rarely spoken about in the newsroom, nor are they generally included in any useable detail when journalists undergo hazardous environment training.

Keywords: conflict reporting, duty of care, hazardous environment training, journalism training, post-traumatic stress disorder, safety training, trauma, war reporting

\section{CAIT MCMAHON}

Dart Centre for Journalism and Trauma-Australasia, Melbourne

Only when the last bodies were recovered did the pair send their footage from the TV station and return to the hotel. They washed the blood and human tissue from their boots in the shower and sat together in shocked silence in their room.

I handed Wayne the bottle of whisky, sat back in silence and let them spill their story out as the bottle emptied. Boris, who was never short of a word to say and usually managed to come up with a quip at the most inopportune moments, just stared at his boots repeating, 'I never want to see that again, I never want to see that again', as if by saying it he could wipe the memory from his brain.

My war gone by, I miss it so. (Loyd, 2001, pp. 280-281)

THE ABOVE words, hauntingly written by foreign correspondent Anthony Loyd, echo from a profound response to his work in covering conflict, the aftermath of genocide and human misery. These are 
not physical wounds that he speaks of, but hidden scars, unseen lesions on the psyche that have imprinted themselves irreparably.

Psychological impacts of covering trauma such as war, or indeed any disaster with loss of life and tragedy, have the capacity to challenge the media professional to develop professional and personal skills. 'Lessons learned' from experience will enhance capacity considerably; however there are also the potential negative effects that can cause harm to some. These effects are rarely spoken about in the newsroom, nor are they generally included in any useable detail when journalists undergo hazardous environment training.

The only comprehensive, psychological research undertaken on war correspondents shows that 28.6 percent of correspondents have a lifetime prevalence of post-traumatic stress disorder (PTSD). This sits alongside clinically significant rates for anxiety, depression and substance use (Feinstein, Owen \& Blair, 2002). This is good news, in that the majority seem to fair well, but to put this figure in context we compare it to American Vietnam Veterans of which 15 percent have lifetime PTSD (Kulka et. al., 1990), and we can see that the figure is considerable.

Reporting is a high risk profession, especially when one covers war zones or regions of civil conflict. Exposure to violence, death and human misery is the daily fare of the war correspondent - all things which can induce feelings of horror, fear and helplessness - the ingredients of PTSD. Learning how to recognise these intense and sometimes debilitating reactions and develop strategies of self care will help media professionals remain psychologically healthy and less prone to place themselves in physically unsafe situations. When people are negatively affected by trauma reactions, judgement and decision making can get 'out of kilter' and can cause the reporter to place themselves or their teams in unnecessary danger. When there is danger all around what is 'safe' gets skewed and there is a higher propensity for risk taking if one's mind is not clear.

It is not only the physical or psychological costs that are at stake; the quality of the journalism may also be impacted. Sharon Schmickle, a Pulitzer finalist, US international correspondent writes, 'The time to care for yourself emotionally is before trauma gradually erodes your ability to think clearly and deliver your best work' (Schmickle, 2007).

It is also argued that a journalist who is 'trauma literate', or aware of the impact of trauma and its reactions will have an extended repertoire of 
understanding that can inform the 'journalism'. Knowing what impact trauma can have on an individual or community will give the reporter language and comprehension that makes for a more in-depth news story. It will also skill the journalist to deal with trauma affected interview subjects in a more ethical and respectful way, which will ultimately lead to a better interview.

Following trauma awareness training for Cambodian journalists covering the Khmer Rouge trials, participant journalist Khou Hav claims his biggest difficulty with interviewees was to 'build trust with them so that they dare to speak out'. He says:

I didn't know this technique before. Asking them about their sufferings and making them cry seemed to make more problems for my interviewees, and I also don't feel well. But now I believe that helping them to speak out can make them feel a sense of relief. (Bun, 2009)

In recent times most 'staff' journalists, camera crews and photographers working for major news organisations are expected to undergo physical safety training before going into hazardous environments, learning first aid, how to wear flak jackets and stay physically safe. Yet, the discussion regarding psychological safety or 'trauma awareness training' is embryonic at best and nonexistent at worst.

In October, 2004, Taiwanese journalist Ping Tsung-cheng died while covering Typhoon Nock-Ten. Ping's death led to a call from journalists to their news organisations for safety training as part of their duty of care. It also prompted the International Federation of Journalists to translate its Live News-A Survival Guide for Journalists (International Federation of Journalists, 2003) into Chinese. While agreements were signed, little has changed for the journalists of Taiwan in terms of physical or psychological safety (Lu, 2009).

It is argued here that physical and psychological 'safety training' must go hand in hand. This belief was also echoed by the International News Safety Institute's 'Jakarta Declaration' of 2008 which states, when speaking about psychological trauma awareness that 'News organisations should observe their Duty of Care for all news personnel they engage and provide appropriate safety and trauma training...'

In 2005, an international group of seasoned war reporters and health professionals convened in New Hampshire, US. The outcome of the gathering was a handy booklet compiled by war journalist Sharon Schmickle which 
gives suggestions of psychological care before, during and after going to war a zone. Salient points from that booklet are presented below, with some 'added extras' and some summaries. Those at the New Hampshire gathering 'concurred that journalists who are equipped to care for themselves emotionally can stay in the field longer, deliver more compelling reports and return home with fewer problems' (Dart Centre, 2009):

\section{Before an assignment}

Develop a self care plan that includes:

- Honestly weighing up the pros and cons

- Reviewing and understanding the risks you are taking

- Talking to experienced reporters who have been before-- 'tap their wisdom'

- Trying to contact those already there

- Planning ahead for your family -insurance, wills, pay bills, work out with your employer what will be covered if you are injured, disabled or killed? Will mental health be included in this?

- Thinking deeply about why you are taking this assignment and what meaning it has for you (this may help your resolve in times when you doubt what you are doing)

- Establishing your contact list of supports for when:

- You are lonely and just need 'normal' chit chat or to laugh

o You need to discuss tough professional issues with

- You have ethical dilemmas (personal or professional) you need to discuss

- You need a senior mentor who has been in the place you have been

- You want to leave.

(These may be the same person or different people for each). Will the cost of calls be covered by your employer?

- Establishing a contact agreement with your editor-when you will make contact and what happens if you don't make contact at that time

- Keeping physically fit, eating well and establishing a relaxation routine (yoga, visualisation, journaling, meditation, etc.)

- Practising deep breathing - this is imperative to use when your heart 
pounds and you are sweating with anxiety in the field-to 'bring yourself down'

- Ensuring bills are paid and insurances are up to date

- Developing an exit strategy.

\section{During the assignment}

1. Maintain contact with your newsroom, home and network of other journalists. Keep regular contact if you can.

2. If replacing others in the field take time to seek their advice.

3. Contact buddies. Colleagues you can let off steam with, laugh with and who will help keep an eye on your decisions for any wearing away of judgment. Look out for each other's safety and co-jointly make a decision as to when to pull out.

There's no formula for deciding when to leave a hotspot. It's pure instinct, and common to feel guilty afterwards, and worrying that you could have stayed longer and done more. Taking a gut-check with someone you trust can save you tremendous anxiety later on. (Schmickle, 2009, p. 13)

4. Try to follow these efficient tips for self care:

- Acknowledge that you are going through a tough time/situation.

- Sleep and eat as well as you can and exercise-even basic stretches

- Journal your thoughts and feelings if you can't chat to a friend

- Reflect on what is happening to you and what it means for you

- Laugh-if there is reason

- Watch excessive substance use if you tend to overindulge already

- Call on your contact list for support-don't be afraid to ask for an 'ear'.

5. Remember you are still human, with normal human responses. You are both a correspondent and a human being, with deep emotions that may surprise the journalist within.

Alissa Rubin, war reporter for both the Los Angeles and New York Times states: 'You are seeing the biggest of the big issues; you are seeing places destroyed, people dead ... enormous emotion.' She says:

The hardest thing will be to go back and forth between your response as a person and as a journalist. A personal revulsion at the sight of 
mangled bodies, for example, will collide with the journalistic need to capture precisely the event you are covering. (Schmickle, 2009, p. 12)

6. Take a break when you feel serious trauma reactions kicking in. In hazardous situations it is normal to feel edgy, jumpy and nervous and not sleep well. The time to be concerned is when these experiences take over your daily functioning and you can't get rid of them. Acute stress signs such as:

- Distressing thoughts, feelings or memories that take hold

- Nightmares

- Acting or feeling that the event is reoccurring

- Upsetting by reminders of the event

- Physical reactions such as a pounding heart, upset stomach, excessive sweating or dizziness

- Problems sleeping

- Unusually irritable or angry

- Problems concentrating

- Unnecessary feelings of being in danger

- Easily jumpy or startled.

\section{Coming home}

This can be a vulnerable time and one of the hardest of the assignment. You have changed but those at home are more or less the same. You may be surprised to experience:

- 'Disappointment with attachments that seem cold compared with the terrible intimacy of watching people, even strangers, bleed and die

- 'Frustration with friends who seem more interested in trivial cultural events than in global matters of war and peace

- 'Discomfort with material abundance that stands in stark contrast to the desperate need in other parts of the world

- 'Alienation from a family that had to make do without you. Your spouse may not need your day-to-day help. Sex may be difficult for a while. Children will have changed and grown into different people with different expectations of adults' (Schmickle, 2009, p. 14)

- A sense of let down, as there may not be another story quite like this one-be prepared to be disappointed in other stories you cover for a while. 
Speak to colleagues or even seek professional help if you experience prolonged periods of these risk factors on your return:

- A sense of being out of control

- Having feelings that your life is threatened when rationally it is not

- Blaming others or yourself

- Shame

- Finding it hard to cope with daily life

- Excessive use of alcohol or drugs.

\section{Notes for editors}

1. Please note different time zones. Calls which interrupt the very little sleep your correspondent is getting will not help their judgment to stay safe, or increase their professional ability.

2. Travel is often difficult in hazardous zones. Calculate thoughtfully where you want your staff to be without moving them around too often and unnecessarily.

3. Always take time to talk to your correspondent if they call-you never know what is going on for them. Listen to them-really listen!

4. Ensure the correspondent, and their family is fully aware of what the terms are for insurance and financial support while they are away. What is the case in injury or death? (Remember psychological injury should be included).

5. Establish a contact plan - ensure someone is available to take calls around the clock from the correspondent. Don't forget the families-remember to keep their family in the loop, even at times when not much is happeningkeep the contact up.

6. Be mindful that often families of correspondents can be deeply impacted by what their loved ones are doing, or even by knowing the place they are in. Check families are okay and link them with support services if needed.

7. Be especially mindful of single correspondents and make sure that they are allowed the same phone call 'rights' to their supports as married reporters are allowed to their families.

8. Be clear about the limits and expectations of risk-taking expected of the correspondent-what conditions may be imposed (e.g. wearing safety gear, areas where they can go) and why.

9. Train all staff in entry level trauma awareness, what to watch out for, and what course of action they should take if they sense someone is not 
'travelling well' regarding trauma exposure.

10. Check in with the correspondent on a regular basis with how they are sleeping and eating.

11. Isolation in the field can exacerbate trauma reactions. Keep them connected to the newsroom and what is going on, without worrying them with minutia.

12. Be generous with praise and encouragement. Say 'thank you'-and be genuine. A common cry of foreign correspondents is that they only hear from those back in the office when they do something wrong.

13. Upon return send someone to the airport to meet the correspondent. Welcome them home with a lunch or some other sort of ritual.

14. Have a logistical debriefing and listen 'between the lines' as to how the correspondent seems to be faring emotionally.

15. Discuss the facts of the event-the what, when, where and how of what they reported on.

16. How did they feel about being away and what they reported on-frustrations and the joys? The highs and the lows. Let them talk.

17. Move to the impact of it all now that they are back-what do they think, how are they doing, how are they feeling?

18. Discuss the normal responses to trauma (as previously mentioned) and keep a 'watchful eye' on them over the coming weeks. Meet with them again in three to four weeks to see how they are going.

19. Encourage the correspondent to meet with or get together with others with similar experiences.

20. If you observe that the correspondent is lacking concentration, missing deadlines, is more accident prone, having angry outbursts, hiding away or conversely constantly talking about their assignment nonstop-or generally any unusual, disturbing behaviour that is out of character for them then do not hesitate to refer them to a health professional who specialises in trauma response. The sooner this can be dealt with the sooner the correspondent can recover and move on.

\section{The families}

Too often the family members follow their loved ones reporting on television, radio or read the bylines and feel powerless to reach out to them, knowing they are being confronted with unimaginable horror and tragedy-most 
of which will never be reported. Therefore, as the main supports of the correspondent, families need to be supported by the employing organisations as well.

It is not unusual during tough assignment periods for communication rifts to occur between the correspondent and loved ones. The correspondent calls home just having dodged bullets and seen death, and the partner is feeding the children and worrying about the broken washing machine. This fissure can cause some distance between the two with neither feeling heard in the moment of the call. Being aware of the potential for such communication issues and speaking about them beforehand can help bridge the gap when these instances occur. Upon returning home there may be a difficult 'transition period' for the correspondent and their families. When the delight of having them home safe has subsided the adjustment to 'normal life' for them can be difficult. They may have been changed by what they have been exposed to. Families and colleagues can help by spending time listening, really listening. Often correspondents have the feeling that no-one can understand unless they have been there. While on one level this may be true, on another it is the voice of trauma that is speaking. Part of what makes trauma what it is, is that the individual feels no-one can understand their experience, because they themselves can't really make sense of it either. Peers and families can assist by familiarising themselves with the risk factors above and keep an open eye for depression, anxiety or acute stress reactions.

\section{Conclusion}

The points made throughout this article serve to briefly highlight psychological self care and duty-of-care strategies for not only war reporters, but all media professionals who are confronted by any form of work-related trauma exposure. It is clear however, that most reporters are extremely resilient and have well developed coping strategies. The points above build on the natural resilience already present in those who serve to bear witness to the best and worst of what the world has to offer. 


\section{REPORTING WARS}

\section{References}

Bun Y, Ung (2009). Reckoning with the Khmer Rouge. Retrieved on 17 January 2010, from http://dartcenter.org/content/reckoning-with-khmer-rouge

Feinstein, A., Owen, J., and Blair, N. (2002). A hazardous profession: War, journalism, and psychopathology. American Journal of Psychiatry, 159, 1570-1576.

International Federation of Journalists (2003). Live news-A survival guide for journalists. Retrieved on 14 January 2010, from www.ifj.org/assets/docs/130/098/ d325b82-7939762.pdf

International News Safety Institute-'Jakarta Declaration' (n.d.). Retrieved on 15 January 2010 , from http://www.newssafety.org/index.php?view=article\&catid= $314 \% 3 \mathrm{Apress}-$ room-news-release $\& \mathrm{id}=10955 \% 3 \mathrm{Ainsi}$-conference-issues-safetycall-for-asia-pacific-\&option=com_content\&Itemid $=100077$

Kulka, R. A., Schlenger, W. E., Fairbank, J. A., Hough, R. L., Jordan, B. K., Marmar, C. R., et al. (1990). The National Vietnam Veterans readjustment study: Tables of findings and technical appendices. New York: Brunner/Mazel.

Loyd, A. (2001). My war gone by, I miss it so. London: Penguin Books.

$\mathrm{Lu}, \mathrm{C}$. (2009). Beyond the pen point-the psychological impact of covering disasters on journalists. Unpublished Masters thesis. Taiwan: National Taiwan University.

Schmickle, S. (2007). Reporting war. Dart Centre for Journalism and Trauma and the Dart Society, Seattle: University of Washington. Also retrievable from http:// dartcenter.org/content/reporting-war-0

Cait McMahon is managing director of the Dart Centre for Journalism and Trauma-Australasia in Melbourne, Australia. This is a project of the Columbia Graduate School of Journalism, New York. McMahon is the only Australian psychologist to be published in the field of journalism and trauma. www.dartcentre.org 
Copyright of Pacific Journalism Review is the property of Auckland University of Technology and its content may not be copied or emailed to multiple sites or posted to a listserv without the copyright holder's express written permission. However, users may print, download, or email articles for individual use.

http://www.aut.ac.nz/depts/commstud/journ/pjrsubs.shtml 